\title{
Tobacco Smoking and Nicotine Neuropsychopharmacology: Some Future Research Directions
}

\author{
Edward F. Domino, M.D.
}

\begin{abstract}
Although nicotine is acknowledged as the major pharmacologically active chemical in tobacco that accounts for its continued use, there is a need for much further research. It is necessary to systematically compare the complex pharmacological actions of pure nicotine with those of tobacco, using different routes of administration and, therefore, rates of absorption. Tobacco smoking produces several important behavioral and central nervous system effects. More research is needed to determine the role of
\end{abstract}

nicotine versus the many other substances present in tobacco smoke. Although nicotine is the primary pharmacological agent in tobacco that maintains its use, other chemicals and their biological mechanisms involved in tobacco smoking need to be studied further.

[Neuropsychopharmacology 18:456-468, 1998] (C) 1998 American College of Neuropsychopharmacology. Published by Elsevier Science Inc.
KEY WORDS: Addiction; Dependence; Dopamine release; MAO inhibition; Nicotine; Pharmacology; Reinforcement; Tobacco

Much is known about the complex issues involved in tobacco smoking reinforcement. Taste, smell, sensory stimulation of the respiratory tract by the smoke, the psychological set, and the social setting of the smoker are all significant. There is little doubt that nicotine is essential for maintaining tobacco smoking behavior (Larson et al. 1961; Ejrup 1965; Larson and Silvette 1968, 1971; U.S. Surgeon General's Report 1988; Balfour 1984; Adlkofer and Thurau 1985; Ney and Gale 1989; Rand and Thurau 1988; Clarke et al. 1995; Domino 1995a). With each passing year more data are available that describe the complex pharmacology of this intriguing alkaloid. One only needs to peruse the abstracts of the So-

From the Department of Pharmacology, University of Michigan, Ann Arbor, MI 48109-0632.

Address correspondence to: E.F. Domino, M.D., Department of Pharmacology, University of Michigan, Ann Arbor, MI 48109-0632.

Received May 7, 1997; revised October 1, 1997; accepted October 3, 1997. ciety for Research on Nicotine and Tobacco meeting in March 1997 and the Society of Neuroscience meeting in October 1997 to appreciate the impressive amount of current nicotinic cholinergic research.

As our knowledge of nicotine pharmacology becomes increasingly more complex, most drug abuse researchers use Occum's razor to explain why a large number of different substances, including nicotine, are reinforcing and, hence, potentially addicting. Most drugs of abuse, including nicotine, release brain dopamine in laboratory rats. Inasmuch as dopamine is the primary neurotransmitter involved in pleasure and reward, the principle of scientific parsimony permits one to conclude that tobacco smoking and dependence are due to nicotine, the resulting dopaminergic neuronal activity and dopamine release (Andersson et al. 1981; Lichtensteiger et al. 1982; Clarke and Kumar 1983a,b; Schwartz et al. 1984; Clarke and Pert 1985; Clarke et al. 1985a, 1988; Grenhoff et al. 1986; Imperato et al. 1986; Grenhoff and Svensson 1988, 1989; Mereu et al. 1987; Clarke 1990; Svensson et al. 1990; Corrigall 1991; Corrigall et al. 1992; Hakan et al. 1993; Bauco and Wise 1994; Nisell et al. 1994, 1995, 1996, 1997). Once the mechanism of nicotine-induced dopamine re- 
lease is well understood, future research directions become individual and administrative choices based upon the needs of society. The purpose of this review is to summarize some of our knowledge and suggest several future directions for nicotine and tobacco research.

\section{A HISTORICAL PERSPECTIVE OF THE RELATIONSHIP OF NICOTINE TO ACETYLCHOLINE}

This has been reviewed briefly by Domino (1995b). More than 83 years ago, Dale (1914) compared the actions of various synthetic and endogenous choline $(\mathrm{Ch})$ derivatives, including acetylcholine (ACh), with those of the plant alkaloids muscarine and nicotine. The effects of muscarine were similar to some of the effects of $\mathrm{ACh}$ and parasympathetic nerve stimulation. The actions of nicotine were similar to those of $\mathrm{ACh}$ after the muscarinic antagonist atropine, as well as after sympathetic nerve stimulation. Dale postulated that ACh was an autonomic nervous system neurotransmitter, and that it had dual actions, i.e., muscarinic and nicotinic.

Nicotine and $\mathrm{ACh}$ can exist in remarkably similar molecular forms. ACh is a very flexible molecule compared with nicotine; it can be easily configured to resemble nicotine. The pyridine nitrogen of nicotine is an electronic donor similar to the keto oxygen of the acetyl group of $\mathrm{ACh}$. The positive charge of the quaternary nitrogen of the $\mathrm{Ch}$ group in $\mathrm{ACh}$ is similar to the positive charge of the pyrrolidine nitrogen of nicotine, which has been emphasized previously (Domino 1979). When using computer graphic techniques, the two molecules are superimposable. At the $\mathrm{pH}$ of blood, nicotine exists in both charged and uncharged forms. The latter can readily penetrate the blood-brain barrier, but ACh cannot. Many years ago, tobacco companies began to add ammonia-forming chemicals to tobacco cigarettes, using the basic concept of the Henderson-Hasselbalch equation. With an alkaline $\mathrm{pH}$, nicotine is more unionized and, therefore, better able to penetrate lipophilic cellular membranes. Pankow et al. (1997) studied this phenomenon in relationship to tobacco smoke particles in which the volatility of conversion of nicotine to its nonprotonated free-base form is facilitated at a basic $\mathrm{pH}$.

A series of studies by Gause and Smaragdova (1938, 1939) and Gause (1941) almost 60 years ago suggested that the mechanism of action of nicotine is related to that of ACh. These investigators studied the toxicity of the optical isomers of nicotine in a large number of invertebrates and vertebrates. In many worms, fish, amphibia, reptiles, and birds, $l$-nicotine is more toxic than $d$-nicotine. In lower forms such as protozoa, coelenterata, platyhelminthes (turbellaria), nemertinea, and trochelminthes (rotatoria), the toxicity of the two isomers of nicotine is equal. Gause (1941) correlated their data with those of Bacq (1935) in animals species that presumably used ACh as a neurotransmitter. The correlation was so impressive that Gause proposed that an optically active receptive substance for nicotine was present in the nervous system of animals that utilized ACh as a neurotransmitter. Hence, Gause in 1941 provided biologic evidence for the existence of a nicotinic cholinergic receptor (nAChR).

\section{BRAIN DISTRIBUTION OF NICOTINIC CHOLINERGIC RECEPTORS}

Schwartz et al. (1982), Clarke and Pert (1984, 1985), Clarke et al. (1985b), London et al. (1985), Schwartz and Kellar (1985), and Schulz et al. (1991) described the autoradiographic distribution of $\mathrm{nAChRs}$ in rat brain using ${ }^{3} \mathrm{H}$-nicotine, ${ }^{3} \mathrm{H}$-ACh, and ${ }^{125} \mathrm{I}-\alpha$-bungarotoxin binding. ${ }^{3} \mathrm{H}$-nicotine binds with high affinity. It is displaced selectively by cold l-nicotine and ACh and less so by $d$-nicotine. The brain distribution of ${ }^{3} \mathrm{H}$-nicotine and ${ }^{3} \mathrm{H}$ ACh is quite different from that of ${ }^{125} \mathrm{I}-\alpha$-bungarotoxin, indicating major subtypes of nAChRs. Both ${ }^{3} \mathrm{H}$-nicotine and ${ }^{3} \mathrm{H}-\mathrm{ACh}$ binding is highest in the interpeduncular nucleus, most thalamic nuclei, superior colliculus, medial habenula, presubiculum, layers I, III, and IV of the cerebral cortex, substantia nigra pars compacta, and the ventral tegmental area. Deutch et al. (1987) and Swanson et al. (1987) used monoclonal antibodies generated against purified AChR from Torpedo electric organ, or chicken and rat brain, to determine the immunohistochemical localization of $\mathrm{nAChR}$ in rat and mouse brain. Again, the pattern of brain distribution is quite different from that of $\alpha$-bungarotoxin binding but similar to that reported for nicotine binding.

\section{MULTIPLE BRAIN NICOTINE BINDING SITES}

In the 1970s and 1980s, researchers characterized rodent brain binding sites for ${ }^{3} \mathrm{H}$-nicotine. The number of nicotine binding sites found varied considerably. Schleifer and Eldefrawi (1974), Abood et al. (1980), and Martin and Aceto (1981) found only one binding site. However, Yoshida and Imura (1979), Romano and Goldstein (1980), Sershen et al. (1981), and Marks and Collins (1982) reported one or two sites, depending upon the temperature and duration of incubation. On the other hand, Sloan et al. (1983, 1984, 1985a,b,c, 1987, 1988) found that ${ }^{3} \mathrm{H}$-nicotine binding was very complex. Multiple sties, including a very high, high, low, and very low affinity, as well as a positive cooperativity site, were described. Sloan et al. also pointed out that nicotine ligands that differed in their binding characteristics had different pharmacological effects, data consistent 
with the presence of multiple nicotinic receptors. Furthermore, as mentioned above, the brain distribution of the binding sites for nicotine differed considerably from those for $\alpha$-bungarotoxin as described by Marks and Collins (1982), Clarke et al. (1985b), and London et al. (1985). It should be noted that Abood et al. (1980) provided evidence for a noncholinergic nicotine binding site. Sloan et al. (1987) pointed out that a number of endogenous brain chemicals, especially niacinamide in a concentration of only $10^{-10} \mathrm{~mol} / \mathrm{L}$, produced a $17 \%$ increase in ${ }^{3} \mathrm{H}$-nicotine binding by an action at an up-regulatory site. One must conclude that there are multiple binding sites for nicotine in the brain; we need to know far more details of the mechanisms involved.

\section{SUBTYPES OF NICOTINIC CHOLINERGIC RECEPTORS}

A great deal of research provided insights into the biological functions of ACh (Mesulam 1994; Reiner and Fibiger 1994) and its muscarinic and nicotinic cholinergic receptor families (Changeaux et al. 1992; Chini et al. 1992; Gerzanich et al. 1993; Lena and Changeaux 1993; Lindstrom et al. 1990; Leutje and Patrick 1991; Sargent 1993; Seguela et al 1993; Sieghart 1992; Steinbach 1990; Tarroni et al. 1992). Muscarinic cholinergic receptors (mAChR) are members of a superfamily of G protein-coupled receptors (Ehlert et al. 1994; Richelson 1994). Nicotinic cholinergic receptors (nAChRs) are members of a superfamily of ligand-gated ion channels with significant molecular diversity (Popot et al. 1976; Conti-Tranconi et al. 1982; Wada et al. 1989; Deneris et al. 1991; Sargent 1993; Arnerić et al. 1995; Bannon et al. 1995). There are now five known muscarinic receptor subtypes $\left(\mathrm{M}_{1}, \mathrm{M}_{2}, \mathrm{M}_{3}, \mathrm{M}_{4}, \mathrm{M}_{5}\right)$ that involve, as second messengers, intracellular decreases in cAMP, increases in PI turnover, or increases in $\mathrm{K}^{+}$conductance. The number of known nicotinic cholinergic receptor subtypes is increasing. The primary composition of nicotinic cholinergic (Numa et al. 1983) and muscarinic cholinergic (Kubo et al. 1986) receptors were determined by using molecular biological techniques that provided amino acid sequences from cloned DNA. Analysis of hydrophobicity plots of their amino acid sequences suggested that nicotinic receptors traverse the plasma membrane four times and muscarinic receptors seven times.

The specific genes for each subunit of nAChRs all encode proteins that are similar to the skeletal muscle $\alpha 1$ subunit in that they contain cysteine 128 and 142 . There are now eight $\alpha$ neuronal genes ( $\alpha 2$ through $\alpha 8$ ). In addition, three neuronal $\beta$ genes $(\beta 2, \beta 3, \beta 4)$ have been described. The subunit mRNA distribution for each varies considerably throughout the nervous system of different species of animals. The nAChRs are divided into three subfamilies as noted in Table 1.

Although the functional role of nAChRs in synaptic transmission in peripheral autonomic ganglia and at the skeletal neuromuscular junction is well documented, their role in synaptic transmission in the brain is far less documented (Sargent 1993; Zhang et al. 1993; McGehee et al. 1995). Especially interesting is electrophysiological evidence that even in synapses mediated by transmitters other than $\mathrm{ACh}$, there may be presynaptic choline acetyltransferase expression and pre- and postsynaptic nAChRs (Brown et al. 1983; Schwartz et al. 1984; Edwards et al. 1992). Wonnacott et al. (1989) and Wonnacott (1997) summarized the evidence for nAChR presynaptically modulating the release of various neurotransmitters. Vidal (1994) suggested that nicotine potentiation of glutamatergic synapses may explain its effects on cognition. McGehee et al. (1995) provided electrophysiological evidence that nicotine in $\mathrm{nmol} / \mathrm{L}$ concentrations via $\mathrm{nAChRs}$ enhances cholinergic and glutamatergic synaptic transmission by increased presynaptic $\left[\mathrm{Ca}^{++}\right]_{\mathrm{i}}$.

Table 1. Subfamilies of Nicotinic Cholinergic Receptors

\begin{tabular}{|c|c|c|c|}
\hline Property & Skeletal Muscle & Autonomic Ganglionic & Central Nervous System \\
\hline Subunits & $\alpha 1, \beta 1, \varepsilon, \delta, \gamma$ & $\alpha 3, \alpha 4, \alpha 5, \alpha 7, \beta 2, \beta 4$ & $\begin{array}{l}\alpha 2, \alpha 3, \alpha 4, \alpha 5, \alpha 6, \alpha 7, \alpha 8, \alpha 9, \beta 2, \\
\quad \beta 3, \beta 4\end{array}$ \\
\hline $\begin{array}{l}\text { Examples of subunit } \\
\text { composition as hetero- or } \\
\text { homo-oligomers }\end{array}$ & $\begin{array}{l}(\alpha 1)_{2} \mathrm{~B} 1 \varepsilon(\text { adult }) \\
(\alpha 1)_{2} \mathrm{~B} 1 \delta \gamma(\text { fetal })\end{array}$ & $\left.(\alpha 4)_{\mathrm{x}} 7\right)_{\mathrm{y}}(\alpha 4)_{\mathrm{x}}(\beta 2)_{\mathrm{y}}$ & $\begin{array}{l}(\alpha 4)_{2}(\beta 2)_{3},(\alpha 3)_{\mathrm{x}}(\beta 2)_{\mathrm{y}} \\
(\alpha 7)_{5},(\alpha 8)_{5},(\alpha 9)_{5}\end{array}$ \\
\hline Effector & $\begin{array}{l}\text { int. } \mathrm{Na}^{+} / \mathrm{K}^{+} / \mathrm{Ca}^{++} \\
\text {(cond. ps large) }\end{array}$ & $\begin{array}{l}\text { int. } \mathrm{Na}^{+} / \mathrm{K}^{+} / \mathrm{Ca}^{++} \text {(cond. } \\
\text { small to large) }\end{array}$ & $\begin{array}{l}\text { int. } \mathrm{Na}^{+} / \mathrm{K}^{+} / \mathrm{Ca}^{++} \text {(cond. small } \\
\text { to large, high } \mathrm{Ca}^{2+} \text { perm.) }\end{array}$ \\
\hline Selective & $\begin{array}{l}{\left[{ }^{3} \mathrm{H}\right]-\text { or }\left[{ }^{125}\right]-} \\
\alpha \text {-bungarotoxin }\end{array}$ & $\begin{array}{l}{\left[{ }^{3} \mathrm{H}\right] \text { cysteine }} \\
{\left[{ }^{3} \mathrm{H}\right] \text { methylcarbamyl-choline }} \\
{\left[{ }^{3} \mathrm{H}\right] \text { nicotine }}\end{array}$ & $\begin{array}{l}{\left[{ }^{3} \mathrm{H}\right]-\text { or }\left[{ }^{125}\right]-\alpha \text {-bungarotoxin }} \\
{\left[{ }^{3} \mathrm{H}\right] \kappa \text {-bungarotoxin }}\end{array}$ \\
\hline Channel blockers & $\begin{array}{l}\text { decamethonium } \\
\text { gallamine }\end{array}$ & $\begin{array}{l}\text { chlorisondomine } \\
\text { hexamethonium } \\
\text { mecamylamine }\end{array}$ & $\begin{array}{l}\text { chlorisondomine } \\
\text { mecamylamine }\end{array}$ \\
\hline
\end{tabular}




\section{OCCUPANCY, RATE, EFFICACY, AND ALLOSTERY RECEPTOR THEORIES-ACTIONS OF NICOTINE ON ITS RECEPTORS}

There are a number of theories regarding drug receptor interactions (Pratt and Taylor 1990; Kenakin 1993). Occupation theory and its extensions include efficacy and allostery models. Classical occupation theory and its extensions involve the mathematical process by which drug molecules bind to the number of their receptors. Rate theory involves the rate of onset and offset of drug molecules binding to their receptor (Paton 1961). As described by Paton, "Instead of thinking of a receptor as, say, a note on an organ, such that as long as it is depressed a note is emitted, we think of it like a piano, one burst of sound and then silence." Rate theory now has few proponents and many feel it has been disproven. Occupancy theory, as developed by Clark (1933), efficacy theory as a modification of occupancy theory Stephenson (1956), and its physical or molecular basis in the allostery model developed by Karlin (1967), Thron (1973), and Lena and Changeaux (1993) are currently the dominant drug-receptor models. Receptor inactivation or desensitization models include those above as well as those described by Katz and Thesleff (1957) and Gosselin (1977). There is a pressing need to explain in mathematical terms the interactions of nicotine with its many different receptors in a unified theory of nicotine receptor activation and deactivation.

\section{TOBACCO AND NICOTINE AS REINFORCERS IN HUMANS}

Not only is the amount of nicotine crucial in the reinforcing effects of tobacco, but also its rate of absorption into the systemic circulation. Smokers given nicotine slowly with a 14-h IV infusion (Benowitz and Jacob 1990), or via a transdermal nicotine patch (Foulds et al. 1992), continue to smoke. The additional nicotine produces a substantially greater increase in venous plasma nicotine levels more than the volunteers usually would obtain after smoking ad lib. Furthermore, the subjects smoke less. These findings confirm earlier reports by Johnston (1942) and Lucchesi et al. (1967). The latter found that an IV nicotine infusion reduced the number of cigarettes smoked by only $22 \%$. Recently, a mouth nicotine inhaler has been used as an adjunct to smoking cessation (Leischow et al. 1996). The smoking abstinence rate following its use was $45 \%$ compared to $14 \%$ $(p<.0005)$ for a placebo inhaler at week 6 , but by month 12 the rate was $11 \%$ and $5 \%$, respectively ( $p=$ .14). It should be noted that although the type of oral nicotine inhaler used delivers reasonable peak plasma levels of nicotine (Molander et al. 1996), it does not deliver nicotine to the lungs but only to the mouth and throat (Bergstrom et al. 1995).
In 1997, $\mathrm{Li}$ et al. and Winchell et al. from the Food and Drug Center for Drug Evaluation and Research reported on all phase III clinical trials related to nicotine products in new drug applications in the United States. A total of 1,953 tobacco smokers were examined for quit rates between nicotine replacement and placebo treated groups. The 4 -week quit rates were $37.2 \%$ for the nicotine treated versus $22.1 \%$ for the placebo group $(p<$ $.0001)$. After 12 months, the quit rates were $14.9 \%$ for the nicotine and $11.1 \%$ for the placebo group $(p<.05)$. Nicotine underdosing was not associated with poorer smoking cessation rates among the nicotine treatment groups with different levels of salivary cotinine. Although the differences between placebo and nicotine replacement therapy groups were statistically significant, the clinical success of nicotine replacement is clearly unimpressive. At 4 weeks, about one of three smokers quit and after 1 year of continuous nicotine therapy only 15 of 100 smokers quit, whereas 85 ex-smokers are back to smoking. Why is nicotine replacement therapy so poorly effective if tobacco smokers are addicted to nicotine? The quantitative data on the rate of nicotine absorption by Armitage et al. (1975) and the pharmacokinetic considerations by Benowitz (1990) following smoking provide clues. Russell et al. (1995) proposed that tobacco smokers regulate their pattern of puffing and inhalation of cigarette smoke to obtain an increase (which they called a boost) of about $10 \mathrm{ng} / \mathrm{ml}$ venous blood within a period of less than $10 \mathrm{~min}$. The blood nicotine boost is defined as the trough concentration before to the peak concentration just after smoking a tobacco cigarette. The nicotine arterial/venous concentration ratio is about $8-10$ just after smoking a cigarette (Armitage et al. 1975; Henningfield et al. 1993). Therefore, the arterial nicotine boost delivered to the human brain must be in the order of $80-100 \mathrm{ng} / \mathrm{ml}$, with a decline to about 25 $\mathrm{ng} / \mathrm{ml}$ within $10 \mathrm{~min}$. Arterial/venous equilibration of nicotine is incomplete $10 \mathrm{~min}$ after finishing smoking a cigarette (Henningfield et al. 1993).

It is of interest that nicotine in gums, skin patches, and inhalers is not pleasurable to most people, in contrast to its use in tobacco. Nicotine skin patches are readily available over the counter in the United States without a prescription and are not abused, probably because they do not provide the short duration nicotine boosts that tobacco smoking does. Is this the only reason most people do not find pure nicotine-containing preparations reinforcing? It should be noted that an extensive series of studies by Jasinski, Henningfield, and colleagues found that IV pulses or smoked nicotine were as pleasurable as cocaine, morphine, or heroin in polydrug abusers (Henningfield et al. 1981, 1983, 1985, 1987; Henningfield and Jasinski 1988; Jasinski and Henningfield 1988; Jasinski et al. 1984; Keenan et al. 1995). Such studies must be repeated in normal nonsmokers and smokers, although significant ethical issues need to 
be settled first. At present, pure nicotine abuse is almost nonexistent compared with tobacco smoking. Why?

Another major area of research concern is the impact of individual differences and the role of psychopathology in human smoking behavior. Gilbert (1995) stressed the issue of individual differences in relationship to a large variety of psychological and biological factors. Pomerleau (1997) reviewed the extensive evidence that psychological/psychiatric co-morbidity with tobacco smoking is present in patients with anxiety disorders, attention deficit-hyperactivity disorders, bulimia/bingeing, and mental depression. Nicotine and other chemicals in tobacco smoke are probably used by such patients as self-medication. Especially pertinent are the studies by Freedman and colleagues, using the positive auditory evoked potential of about $50 \mathrm{~ms}$ as an electrophysiological marker for schizophrenia. This positive potential (P1, also known as P50) has been used as an index of processing auditory input in schizophrenic patients (see Adler et al. 1982, 1992; Freedman et al. 1983, 1987, 1991; Waldo et al. 1991). The testing paradigm they used is related to prepulse inhibition of the startle response. Tobacco smoking/nicotine transiently reversed this deficit in sensory gating in schizophrenic patients and some of their mentally normal relatives. Freedman et al. (1983) demonstrated that the P1 gating mechanism involves a nicotinic cholinergic mechanism via an $\alpha$-bungarotoxin sensitive receptor. It is of interest that Knott (1989) summarized data that the P1 potential is enhanced in mentally normal volunteers by tobacco smoking.

The mechanism by which nicotine in combination with haloperidol is a treatment of Tourette's syndrome (Silver and Sanberg 1993) needs further study, as does the relationship of nicotine to Parkinson's and Alzheimer's diseases (Smith and Giacobini 1992).

\section{NICOTINE ALONE IS REINFORCING IN ANIMALS}

There is no question that nicotine is a positive reinforcer in animals. The first report by Deneau and Inoki (1967) indicated that monkeys self-administer nicotine. Perhaps because nicotine is not as reinforcing in animals as cocaine there was early disagreement among investigators as to how reinforcing nicotine really was. The early literature is well summarized in the U.S. Surgeon General's report in 1988. Since then, the evidence that nicotine alone is a positive reinforcer in animals is overwhelming. In addition, animals readily discriminate nicotine in appropriate behavioral paradigms (Stolerman 1989; Rosecrans et al. 1995). Strain differences are important, indicating genetic factors must be considered.

Genetic factors in rats are impressive (Shoaib et al. 1997). For example, Corrigall and Coen (1989) studied Long-Evans rats that show robust self-administration of nicotine, whereas Dworkin et al. (1993) studied Wistar rats that do not. Rosecrans (1971) showed that female rats selected for activity differences differ in their behavioral and 5-hydroxytryptamine brain effects. Individual differences are marked (Rosecrans 1995). Furthermore, nicotine stimulus discrimination varies markedly among different rat strains (Rosecrans et al. 1995). Although genetic factors are very important in nicotine reinforcement, the conditions in which rats were previously trained to drugs like cocaine (Tessari et al. 1995) are an indication of important conditioning, etc., factors (Shoaib et al. 1997).

\section{IS TOBACCO SMOKING ADDICTION DUE TO NICOTINE ALONE?}

A hypothesis championed by proponents of the tobacco industry is that the effects of tobacco cigarette smoking are more complex than those due to nicotine alone. Perhaps an appropriate nicotine boost, as well as the possible effects of the thousand or more other chemicals in tobacco smoke, is involved in maintaining tobacco smoking behavior. It is not the purpose of this communication to review the chemistry of tobacco and its smoke (see Schmeltz and Hoffman 1976). Jarvik's review (1979) includes a short list of substances in the gas and tar phase of cigarette smoke, which is a cesspool of chemicals that may have some biological effects. What substances in tobacco smoke besides nicotine have behavioral, nervous system, or other actions throughout the body? Almost everybody agrees with the widely held belief that the primary pharmacologically active agent in tobacco is nicotine. However, other chemicals in tobacco smoke contribute to its smell, taste, and complex biological effects. It is essential to compare the effects of pure nicotine with those of tobacco smoke on various biological and psychological measures. As described above, one must keep in mind the route and speed by which tobacco versus nicotine is taken into the body. The various tobacco/nicotine delivery systems are compared in Table 2.

The rate of absorption and dose of nicotine are crucial variables that determine its pharmacological actions. There are rapid but variable rates of desensitization of various nicotinic cholinergic receptors, which lead to differential tachyphylaxis and tolerance. It makes little pharmacological sense to compare the effects of the inhalation of tobacco smoke with those produced by a nicotine patch. One must compare the effects of tobacco and pure nicotine via the same route of administration and same rate of absorption. Skin absorption of both is the slowest, oral gum slow, snuff and nasal spray a little faster, and pipe smoking and mouth inhalation intermediate. Cigarette smoking and aerosol inhalation produce the fastest absorption of active compounds. Nicotine aerosol inhalers developed 
Table 2. Tobacco/Nicotine Delivery Systems

\begin{tabular}{lll}
\hline Tobacco & \multicolumn{1}{c}{ Nicotine } & \multicolumn{1}{c}{ Absorption } \\
\hline Mouth (oral snuff) & Gum & Slow \\
Skin contact & Patch & Slowest \\
Nasal snuff & Nasal spray & Intermediate \\
Enema & Enema & Intermediate \\
Cigar, pipe & Mouth inhaler & Intermediate \\
Cigarette & Aerosol inhaler & Fast \\
Not applicable & Injection, SC, IM, IV & Intermediate to fastest \\
\hline
\end{tabular}

years ago (Herxheimer et al. 1967; Domino and Lutz 1973) were very irritating and not practical in delivering pure nicotine via lung absorption. With new propellants and the technologies used in current asthmatic inhalers, this problem should be overcome. One can also use pure nicotine injections SC, IM, and IV. The rates of absorption from these routes are intermediate to very fast. It is not very practical, but tobacco has been used by local skin application and rectal administration. Inasmuch as ulcerative colitis is a disease primarily of nonsmokers, and transdermal nicotine patches are helpful, Green et al. (1977) developed a nicotine polyacrylic carbomer administered by enema to treat patients with active disease. In the case of ulcerative colitis, it appears that the beneficial effects of tobacco smoking are those due to nicotine itself and not other chemicals in tobacco.

Dramatic visual evidence from the human positron emission tomography (PET) imaging study by Fowler et al. (1996) shows that there is more to tobacco smoke than nicotine. It was known for many years that something in tobacco smoke inhibits monoamine oxidase (MAO; Essman 1977; Oreland et al. 1981; Norman et al. 1982, 1987; Yu and Boulton 1987; Boulton et al. 1988; Berlin et al. 1995). There are two types of MAO involved in the oxidative deamination of biogenic amine chemical modulators and neurotransmitters. Fowler et al. (1996) showed more reduced brain $\mathrm{MAO}_{\mathrm{B}}$ than $\mathrm{MAO}_{\mathrm{A}}$ binding in tobacco smokers compared with nonsmokers. Nonsmokers were pretreated with nonradioactive deprenyl to inhibit their brain $\mathrm{MAO}_{\mathrm{B}}$ as a control. In neither the deprenyl-treated nonsmokers nor the tobacco smokers was ${ }^{11} \mathrm{C}$-deprenyl taken up as well by the brain. Nicotine itself is not an MAO inhibitor. Something else besides nicotine in tobacco smoke produces MAO inhibition. Is the percentage of inhibition in vivo sufficient for a functional decrease in MAO activity? The time has come for more research on this issue.

\section{TOLERANCE, SENSITIZATION, AND WITHDRAWAL TO NICOTINE AND TOBACCO SMOKING}

Nicotine is well known to produce rapid (tachyphylaxis) and slower tolerance. Any person who smoked a first tobacco cigarette knows the initial effects of smoking may be very unpleasant with subsequent tolerance. Interestingly, even regular tobacco smokers lose some tolerance overnight to the side effects of the first cigarette smoked in the morning. There are very important differential genetic components to nicotine-induced tolerance and $\mathrm{nAChR}$ changes as described by Marks et al. (1986) in four different inbred mouse strains. In contrast to $\mathrm{C} 57 \mathrm{BL}, \mathrm{BALB}$, and DBA animals, $\mathrm{C} 3 \mathrm{H}$ mice did not develop tolerance to nicotine effects on Y-maze activity, rearing, and body temperature. However, $\mathrm{C} 3 \mathrm{H}$ mice showed tolerance to nicotine on acoustic startle. None of the four strains developed tolerance to nicotine effects on respiration. Only the BALB mice showed tolerance to nicotine-induced bradycardia. All four strains had increased $\left[{ }^{3} \mathrm{H}\right]$ nicotine binding in six different brain regions with slight strain differences in $\alpha\left[{ }^{125} \mathrm{I}\right]$ bungarotoxin binding to chronic nicotine. The significance of the paradox of increased nAChR upregulation with chronic nicotine has been reviewed by Wonnacott (1990).

Damsma et al. (1989) found no tolerance to nicotineinduced dopamine release in nucleus accumbens. Such animal studies have important implications for the effects of nicotine and tobacco smoking in humans and may help explain some of the individual differences and perplexities of tobacco smoking. Detailed studies on the tolerance development to different pharmacological effects of nicotine are needed, similar to those described by Porchet et al. $(1987,1988)$ on heart rate.

One of the simplest behavioral effects of nicotine in rodents is alteration of locomotor activity. In mice, nicotine produces either an increase or decrease of activity, depending upon the dose and the genetic strain. Very marked pharmacogenetic differences to nicotine are observed in pure bred mouse strains (Bovet et al. 1969; Collins et al. 1988). When nicotine is given in a single dose to most strains of naive adult rats, locomotor activity is reduced. However, when nicotine is given daily, tolerance occurs to its depressant effects both on locomotor activity as well as in various operant paradigms (Morrison 1967; Morrison and Stephenson 1972; Domino and Lutz 1973; Stolerman et al. 1973; Rosecrans et al. 1989; Belwell and Balfour 1992; Villaneuva et al. 1992). On repeated administration, nicotine induced rat behavioral stimulation becomes very apparent (Morrison and Stephenson 1972; Clarke and Kumar 1983a,b; Ksir et al. 1985, 1987; Hakan and Ksir 1988, 1991; Johnson 1995). In addition, the sensitivity of rat frontal cortical neurons is increased by chronic nicotine (Abdulla et al. 1995). The same daily nicotine treatment schedule does not cause dramatic behavioral sensitization in hemiparkinsonian monkeys, suggesting important species or brain pathological differences (Domino et al. 1998). Hence, the need for more research. Does nicotine-induced behavioral sensitization, so easily observed in rats, occur in primates, and especially in humans? 
The 1988 U.S. Surgeon General's Report summarized the evidence that abrupt withdrawal from nicotine/tobacco resulted in an abstinence syndrome. There is a significant interrelationship between conditioned and primary reinforcement in the maintenance of tobacco smoking (Rose and Levin 1991), but also in the extent of its withdrawal signs and symptoms. Hildebrand et al. (1997) used centrally and peripherally acting nicotinic antagonists to precipitate an abstinence syndrome in rats given nicotine, $10.27 \mathrm{mg} / \mathrm{kg} /$ day for 7 days. They concluded that central as well as peripheral nicotinic receptors contribute to the withdrawal syndrome. Abdulla et al. (1996) found that chronic nicotine given to rats produced regional brain increases in $\left[{ }^{3} \mathrm{H}\right]$-nicotine binding in some areas such as the frontal, entorhinal, and dorsal hippocampus, but not in other areas such as the posterior cingulate or ventral hippocampus. Nicotine clearly improved the rate of learning. These investigators studied the relationship between upregulation of nicotine binding sites and the cognitive enhancement after acute or chronic nicotine. Nicotine, given only for 1 day 11 days earlier, increased the rate of learning, but only marginally increased nicotinic receptor binding in the entorhinal cortex and not in other brain areas. Entorhinal and dorsal hippocampal nicotinic binding was positively correlated with the rate of learning. Clearly, much more research needs to be done on the relationship of improvement in learning and the significance of differential regional upregulation of both active and desensitized nAChRs, and which ones. Lake et al. (1997) reported in an abstract that in rats given a SC nicotine infusion in a dose of $9 \mathrm{mg} / \mathrm{kg} /$ day for 7 days, abrupt termination, injection of nicotine, the SC injection of mecamylamine, dihydro- $\beta$-erythroidine, or cerebral intraventricular (IVT) hexamethonium, but not scopolamine, induce an abstinence syndrome. The animal data indicate that nicotinic cholinergic antagonists such as mecamylamine precipitate a withdrawal syndrome in nicotine-dependent rats. However, mecamylamine, in doses up to $20 \mathrm{mg}$ orally, does not precipitate a withdrawal syndrome in chronic tobacco smokers (Eissenberg et al. 1996). Perhaps much larger doses of mecamylamine are needed, but this will result in significant side effects due to mecamylamine alone. Obviously, much more research is needed to pursue this important issue.

\section{NEED FOR APPROPRIATE COMPARISON STUDIES WITH NICOTINE ALONE AND VARIOUS TOBACCO PRODUCTS}

Russell et al. (1995) concluded that a similar venous blood nicotine boost occurs within $10 \mathrm{~min}$ with both smokeless oral tobacco snuff and nicotine spray, but not with nicotine gum or patches. The best method of duplicating the puff by puff inhalation of tobacco smoke is the use of a nicotine aerosol. Until a nonirritating nicotine aerosol is developed, which can deliver nicotine to the lungs, the inhalation method of administering nicotine is not an option.

Pure nicotine solutions have been given to humans via various routes of injection including IV, IM, or SC. However, such methods of administration require an investigational new drug application to the U.S. Food and Drug Administration and, therefore, are of limited availability. Furthermore, institutional human use committees are far more concerned with protocols that deal with nicotine by injection than by patch, gum, or nasal spray. Obviously, computer programmed intravenous injections of nicotine that mimic the blood concentrations of nicotine obtained from inhaling tobacco smoke are of special interest. If an average tobacco smoker obtains about 10 total $0.1 \mathrm{mg} /$ puff doses of nicotine in about $5 \mathrm{~min}$, appropriate computer programming of small, very rapid bolus IV injections could mimic cigarette smoking. To do so, the injection system must deliver an IV nicotine bolus within $2 \mathrm{~s}$. Corrigall and Coen (1989) used a pneumatic pump which delivered a 1-s pulse of nicotine each time a rat pressed an operant bar. A modified system using a microdialysis pump is being developed by Matta and colleagues from the Minneapolis Medical Research Foundation (personal communication 1997). Such a technique is still highly experimental and not a U.S. FDA approved method for humans. Therefore, from a practical point of view, at the present time intranasal administration of nicotine seems to be the only reasonable approach to compare pure nicotine with tobacco smoke inhalation. Fortunately, the FDA in 1996 approved a nicotine nasal spray device. This device delivers $0.5 \mathrm{mg} /$ spray. Nicotine can easily be administered in doses of 1-2 mg total with one to two sprays into each nostril. Obviously, the next studies to be done are to compare the effects of intranasal nicotine with the results obtained with tobacco smoking.

\section{FUTURE DIRECTIONS}

We humans usually have free choice to decide on the harm/benefit of most behaviors that directly affect us. Much is known of the harmful effects of tobacco smoking, but a lot less about its benefits, which many in our society feel are none. Jarvik (1991) described some of the beneficial effects of nicotine. From a scientific point of view, society must do far more in providing support for studying the latter. Developing safer tobacco smoking devices is the job of the tobacco industry, but developing substitutes for the positive reinforcing effects of tobacco smoking is the job of motivated scientists and the pharmaceutical industry. The tobacco problem will not go away with a prohibition on smoking. Current agreements and negotiations among private, state, and 
federal representatives and the tobacco industry are heading in the direction of allowing the tobacco industry to survive but be far more regulated. One can conclude that the 21st century will have many people well informed of the hazards of tobacco smoking who will continue to smoke. Hence, safer tobacco products, as well as much more scientific knowledge on why people smoke, need to be obtained through research. Agreements between legislative bodies and the tobacco industry should include funds to support such research, or more taxes on tobacco products should be designated for research.

\section{ACKNOWLEDGMENTS}

This work was supported in part by the Psychopharmacology Research Fund 361024 and NIDA Grant R01 DA-10992-01.

\section{REFERENCES}

Abdulla FA, Calaminici M, Wonnacott S, Gray JA, Sinden JD, Stephenson JD (1995): Sensitivity of rat frontal cortical neurons to nicotine is increased by chronic administration of nicotine and by lesions of the nucleus basalis magnocellularis. Synapse 21:281-288

Abdulla FA, Bradbury E, Calaminici M-R, Lippiello PM, Wonnacott S, Gray JA, Sinden JD (1996): Relationship between up-regulation of nicotine binding sites in rat brain and delayed cognitive enhancement observed after chronic or acute nicotinic receptor stimulation. Psychopharmacology 124:323-331

Abood LG, Reynolds DT, Bidlack JM (1980): Stereospecific $\left[{ }^{3} \mathrm{H}\right]$-nicotine binding to intact and solubilized rat brain membranes and evidence for its noncholinergic nature. Life Sci 27:1307-1314

Adler LE, Hoffer LJ, Griffith J, Waldo M, Freedman R (1992): Normalization of deficient auditory sensory gating in the relatives of schizophrenics by nicotine. Biol Psychiatry 32:607-616

Adler LE, Pachtman E, Franks RD, Percevich M, Waldo MC, Freedman R (1982): Neurophysiological evidence for a defect in neuronal mechanisms involved in sensory gating in schizophrenia. Biol Psychiatry 17:639-654

Adlkofer F, Thurau K (eds) (1985): Effects of Nicotine on Biological Systems, Advances in Pharmacological Sciences. Boston, Birkhäuser Verlag, pp 1-646

Andersson F, Fuxe K, Agnati FL, Eneroth P (1981): Effects of acute central and peripheral administration of nicotine on ascending dopamine pathways in the male rat brain. Evidence for nicotine induced increases of dopamine turnover in various telencephalic dopamine nerve terminal systems. Med Biol 59:170-176

Armitage AK, Dollery CT, George CF, Houseman TH, Lewis PJ, Turner DM (1975): Absorption and metabolism of nicotine from cigarettes. Br Med J 4:313-316

Arnerić SP, Sullivan JP, Williams M (1995): Neuronal nicotinic acetylcholine receptors-Novel targets for central nervous system therapeutics. In Bloom FE, Kupfer DJ (eds), Psychopharmacology: The Fourth Generation of Progress, chap 9. New York, Raven Press, pp 95-110

Bacq ZM (1935): La transmission chimique des influx dans le systeme nerveaux autonome. Erg Physiol 37:82-185

Balfour DJK (ed) (1984): Nicotine and the Tobacco Smoking Habit. International Encyclopedia of Pharmacology and Therapeutics, Section 114. New York, Pergamon Press, pp 1-221

Bannon AW, Decker MW, Williams M, Arneric SP (1995): Psychotherapeutic potential of selective neuronal nicotine acetylcholine receptor ligands. In Domino EF (ed), Brain Imaging of Nicotine and Tobacco Smoking. Ann Arbor, NPP Books, pp 311-334

Bauco P, Wise RA (1994): Potentiation of lateral hypothalamic and midline mesencephalic brain stimulation reinforcement by nicotine: Examination of repeated treatment. J Pharmacol Exp Ther 271:294-301

Belwell MEM, Balfour DJK (1992); The effects of acute and repeated nicotine treatment on nucleus accumbens dopamine and locomotor activity. Br J Pharmacol 105: 849-856

Benowitz NL (1990): Pharmacokinetic considerations in understanding nicotine dependence. In Bock G, Marsh J (eds), Ciba Foundation Symposium 152. New York, John Wiley \& Sons, pp 186-209

Benowitz NL, Jacob P (1990): Intravenous nicotine replacement suppresses nicotine intake from cigarette smoking. J Pharmacol Exp Ther 254:1000-1005

Bergström M, Nordberg A, Lunell E, Antoni G, Långstöm B (1995): Regional deposition of inhaled ${ }^{11} \mathrm{C}$-nicotine vapor in the human airway as visualized by positron emission tomography. Clin Pharmacol Ther 57:309-317

Berlin I, Said S, Speux-Varoquaux O, Olivares R, Launay J-M, Puech AJ (1995): Monoamine oxidase A and B activities in heavy smokers. Biol Psychiatry 38:756-761

Boulton AA, Yu PH, Tipton KF (1988): Biogenic amine adducts, monoamine oxidase inhibitors and smoking. Lancet 1:114-115

Bovet D, Bovet-Nitti F, Oliverio A (1969): Genetic aspects of learning and memory in mice. The study of differences among strains and individual subjects is a most promising topic in psychobiology. Science 163:139-149

Brown DA, Docherty RJ, Halliwell JV (1983): Chemical transmission in the rat interpeduncular nucleus in vitro. J Physiol 341:655-670

Changeaux JP, Galzi JL, Devillers-Thiery A, Bertrand D (1992): The functional architecture of the acetylcholine nicotine receptor explored by affinity labeling and sitedirected mutagenesis. Q Rev Biophys 25:395-432

Chini B, Clementi F, Hukovic N, Sher E (1992): Neuronal $\alpha$-bungarotoxin receptors and the $\alpha 5$-nicotinic receptor subunit gene are expressed in neuronal and non-neuronal human cells lines. Proc Natl Acad Sci USA 89:1572-1576

Clark AJ (1933): The Model of Action of Drugs on Cells. London, E. Arnold and Co.

Clarke PBS (1990): Mesolimbic dopamine activation-The key to nicotine reinforcement? In Bock G, Marsh J (eds), The Biology of Nicotine Dependence, Ciba Foundation Symposium 152. New York, John Wiley \& Sons, pp 153-168 
Clarke PBS, Kumar R (1983a): The effects of nicotine on locomotor activity in tolerant and nontolerant rats. $\mathrm{Br} \mathrm{J}$ Pharmacol 78:329-337

Clarke PBS, Kumar R (1983b): Characterisation of the locomotor stimulation action of nicotine in tolerant rats. Br J Pharmacol 80:587-594

Clarke PBS, Pert A (1984): Autoradiographic distribution of nicotine receptors in rat brain. Brain Res 323:390-395

Clarke PBS, Pert A (1985): Autoradiographic evidence for nicotinic receptors on nigrostriatal and mesolimbic dopaminergic neurons. Brain Res 348:355-358

Clarke PBS, Fu DS, Jakubovic A, Fibiger HC (1988): Evidence that mesolimbic dopaminergic activation underlies the locomotor stimulant action of nicotine in rats. J Pharmacol Exp Ther 246:701-708

Clarke PBS, Hommer DW, Pert A, Skirboll LR (1985a): Electrophysiological actions of nicotine on substantia nigra single units. Br J Pharmacol 85:827-835

Clarke PBS, Schwartz RD, Paul SM, Pert CD, Pert A (1985b): Nicotinic binding in rat brain autoradiographic comparison of $\left[{ }^{3} \mathrm{H}\right]$ acetylcholine, $\left[{ }^{3} \mathrm{H}\right]$ nicotine, and $\left[{ }^{125}\right]-\alpha-b u n-$ garotoxin. J Neurosci 5:1307-1315

Clarke PBS, Quik M, Adlkofer F, Thurau K (eds) (1995): Effects of Nicotine on Biological Systems II. Advances in Pharmacological Sciences. Boston, Birkhäuser Verlag

Collins AC, Miner LL, Marks MJ (1988): Genetic influences on acute responses to nicotine and nicotine tolerance in the mouse. Pharmacol Biochem Behav 30:269-278

Conti-Tranconi BM, Hunkapiller MW, Lindstrom JM, Raftery A (1982): Subunit structure of the acetylcholine receptor from electophorus electricus. Proc Natl Acad Sci USA 79:6489-6493

Corrigall WA (1991): Understanding brain mechanisms in nicotine reinforcement. $\mathrm{Br}$ J Addict 86:507-510

Corrigall WA, Coen KM (1989): Nicotine maintains robust self-administration in rats on a limited-access schedule. Psychopharmacology 99:473-478

Corrigall WA, Franklin KBJ, Coen KM, Clarke PBS (1992): The mesolimbic dopaminergic system is implicated in the reinforcing effects of nicotine. Psychopharmacology 107:285-289

Dale HH (1914): The action of certain esters and ethers of choline and their relation to muscarine. J Pharmacol Exp Ther 6:147-190

Damsma G, Day J, Fibiger HC (1989): Lack of tolerance to nicotine-induced dopamine release in the nucleus accumbens. Eur J Pharmacol 168:363-368

Deneau GA, Inoki R (1967): Nicotine self-administration in monkeys. Ann NY Acad Sci 142:277-279

Deneris ES, Connolly J, Rogers SW, Duvoisin R (1991): Pharmacological and functional diversity of neuronal nicotinic acetylcholine receptors. Trends Pharmacol Sci 12:34-40

Deutch AY, Holliday J, Roth RH, Chun LLY, Hawrot E (1987): Immuno-histochemical localization of a neuronal nicotinic acetylcholine receptor in mammalian brain. Proc Natl Acad Sci USA 84:8697-8701

Domino EF (1983): Neuropsychopharmacology of nicotine and tobacco smoking. In Dunn WL Jr (ed), Smoking
Behavior: Motives and Incentives. Washington, DC, V.H. Winston and Sons, pp 5-31

Domino EF (1979): Behavioral, electrophysiological, endocrine, and skeletal muscle actions of nicotine and tobacco smoking. In Remond A, Izard C (eds), Electrophysiological Effects of Nicotine. Amsterdam, Elsevier/ North Holland Biomedical Press, pp 133-146

Domino EF (ed) (1995a): Brain Imaging of Nicotine and Tobacco Smoking. Ann Arbor, NPP Books

Domino EF (1995b): Significance of multiple nicotine cholinergic receptors for tobacco use. In Domino EF (ed), Brain Imaging of Nicotine and Tobacco Smoking. Ann Arbor, NPP Books, pp 1-12

Domino EF, Lutz MP (1973): Tolerance to the effects of daily nicotine on rat bar pressing behavior for water reinforcement. Pharmacol Biochem Behav 1:445-448

Domino EF, Ni LS, Zhang H (1998): Nicotine alone and in combination with dopamine agonists in MPTP induced hemiparkinsonian monkeys. J Pharmacol Exp Ther, in press

Dworkin SI, Vrana SL, Broadbent J, Robinson JH (1993): Comparing the reinforcing effects of nicotine, caffeine, methylphenidate and cocaine. Med Chem Res 2:593-602

Edwards FA, Gibb AJ, Colquhoun D (1992): ATP receptormediated synaptic currents in the central nervous system. Nature 359:144-147

Ehlert FJ, Roeske WR, Yamamura HI (1994): Molecular biology, pharmacology, and brain distribution of subtypes of the muscarinic receptor. In Bloom FE, Kupfer DJ (eds), Psychopharmacology: The Fourth Generation of Progress, chap. 10. New York, Raven Press, pp 111-124

Eissenberg G, Griffiths RR, Stitzer ML (1996): Mecamylamine does not precipitate withdrawal in cigarette smokers. Psychopharmacology 127:328-336

Ejrup B (1965): The role of nicotine in smoking pleasure, nicotinism, treatment. In von Euler US (ed), Tobacco Alkaloids and Related Compounds. New York, Pergamon Press Book, The Macmillan Co, pp 333-346

Essman WB (1977): Serotonin and monoamine oxidase in mouse skin: Effects of cigarette smoke exposure. J Med 8:95-101

Foulds J, Stapleton J, Feyerabend C, Vesey C, Jarvis M, Russell MAH (1992): Effect of transdermal nicotine patches on cigarette smoking: A double-blind crossover study. Psychopharmacology 106:421-427

Fowler JS, Volkow ND, Wang G-J, Pappas N, Logan J, MacGregor R, Alexoff D, Shea C, Schlyer D, Wolf AP, Warner D, Zezulkova I, Cilento R (1996): Inhibition of monoamine oxidase B in the brains of smokers. Nature 379:733-736

Freedman R, Mirsky AF (1991): Event-related potentials: Exogenous components. In Steinhauser SR, Gruzelier JH, Zubin J (eds), Neuropsychology, Psychophysiology, and Information Processing. Handbook of Schizophrenia, vol. 5. Amsterdam, Elsevier, pp 71-90

Freedman R, Adler LE, Waldo MC, Pachtman E, Franks RD (1983): Neurophysiological evidence for a defect in inhibitory pathways in schizophrenia: Comparison of medicated and drug-free patients. Biol Psychiatry 18: 537-551

Freedman R, Adler LE, Gerhardt GA, Waldo M, Baker N, 
Rose GM, Drebing C, Nagamoto H, Bickford-Wimer P, Franks R (1987): Neurobiological studies of sensory gating in schizophrenia. Schizophr Bull 13:669-678

Gause GF (1941): Analysis of various biological processes by the study of the differential action of optical isomers. Biodynamica 3:217-246

Gause GF, Smaragdova NP (1938): Investigations on the toxicity of nicotine isomers in connection with some problems of the evolution of the CNS in animals. Biol $\mathrm{Zh}$ Arm 7:412-428

Gause GF, Smaragdova NP (1939): On the killing action of optically isomeric nicotines in relation to problems of evolution of the nervous system in animals. Physiol Zool 12:238-255

Gerzanich V, Annand R, Lindstrom J (1993): $\mathrm{Ca}^{2+}$ permeable $\alpha 8 \mathrm{AChR}$ functionally expressed in Xenopus oocytes exhibits significantly different pharmacology from $\alpha 7$ AChR. Soc Neurosci Abst 23:11

Gilbert DG (1995): Smoking-Individual Differences, Psychopathology, and Emotion. Washington, DC, Taylor and Francis

Gosselin RE (1977): Drug-receptor inactivation. A new kinetic model. In Von Rossum JM (ed), Kinetics of Drug Action. Berlin, Springer Verlag, pp 323-356

Green JT, Thomas GAO, Rhodes J, Evans BN, Russell MAH, Feyerabend C, Fuller GS, Newcombe RG, Sandborn WJ (1977): Pharmacokinetics of nicotine carbomer enemas: A new treatment modality for ulcerative colitis. Clin Pharmacol Ther 61:340-348

Grenhoff J, Svensson TH (1988): Selective stimulation of limbic dopamine activity by nicotine. Acta Physiol Scand 133:595-596

Grenhoff J, Svensson TH (1989): Pharmacology of nicotine. Br J Addict 84:477-492

Grenhoff J, Aston-Jones G, Svensson TH (1986): Nicotinic effects on the firing pattern of midbrain dopamine neurons. Acta Physiol Scand 128:351-358

Hakan RL, Hart C, Eyl C (1993): Specific neurophysiological effects of systemic nicotine on neurons in the nucleus accumbens. Synapse 15:191-197

Hakan RL, Ksir CJ (1988): Nicotine induced locomotor activity in rats: The role of Pavlovian conditioning. Pharmacol Biochem Behav 29:661-665

Hakan RL, Ksir CJ (1991): Acute tolerance to the locomotor stimulant effect of nicotine in the rat. Psychopharmacology 104:386-390

Henningfield JE, Jasinski DR (1988): Pharmacologic basis for nicotine replacement. In Pomerleau OF, Pomerleau CS, Fagerström KO, Henningfield JE, Hughes JR (eds), Nicotine Replacement-A Critical Evaluation. New York, Alan R Liss Inc, pp 35-61

Henningfield JE, Miyasato K, Johnson RE, Jasinski DR (1981): Nicotine: Behavioral and physiological effects and self-administration in humans. Pharmacol Biochem Behav 15:830

Henningfield JE, Miyasato K, Jasinski DR (1983): Cigarette smokers self-administer intravenous nicotine. Pharmacol Biochem Behav 19:887-890

Henningfield JE, Miyasato K, Jasinski DR (1985): Abuse liabil- ity and pharmacodynamic characteristics of intravenous and inhaled nicotine. J Pharmacol Exp Ther 234:1-12

Henningfield JE, Goldberg SR, Jasinski DR (1987): Nicotine: Abuse liability, dependence potential and pharmacologic treatment of dependence. In Martin WR, VanLoon GR, Iwamoto ET, Davis L (eds), Tobacco Smoking and Nicotine-A Neurobiological Approach. New York, Plenum Press, pp 81-99

Henningfield JE, Stapleton JM, Benowitz NL, Grayson RF, London ED (1993): Higher levels of nicotine in arterial than in venous blood after cigarette smoking. Drug Alcohol Depend 33:23-29

Herxheimer A, Griffiths RL, Hamilton B, Wakefield M (1967): Circulatory effects of nicotine aerosol inhalations and cigarette smoking in man. Lancet 2:754-755

Hildebrand BE, Nomikos CG, Bondjers C, Nisell M, Svensson TH (1997): Behavioral manifestations of the nicotine abstinence syndrome in the rat: Peripheral versus central mechanisms. Psychopharmacology 129:348-356

Imperato A, Mulas A, DiChiara G (1986): Nicotine preferentially stimulates dopamine release in the limbic system of freely moving rats. Eur J Pharmacol 132:337-338

Jarvik ME (1979): Biological influences on cigarette smoking. In Krasnegor NA (ed), The Behavioral Aspects of Smoking, NIDA Research Monograph 26. Washington, DC, US Government Printing Office, pp 7-45

Jarvik ME (1991): Beneficial effects of nicotine. Br J Addict 86:571-575

Jasinski DR, Henningfield JE (1988): Conceptual basis for replacement therapies for chemical dependence. In Pomerleau OF, Pomerleau CS, Fagerström KO, Henningfield JE, Hughes JR (eds), Nicotine ReplacementA Critical Evaluation. New York, Alan R Liss Inc, pp 13-34

Jasinski DR, Johnson RE, Henningfield JE (1984): Abuse liability assessment in human subjects. Trends Pharmacol Sci 5:196-200

Johnson DH (1995): Behavioral sensitization to nicotine. Ph.D. thesis, University of Göteborg, Sweden, pp 1-42

Johnston LM (1942): Tobacco smoking and nicotine. Lancet $2: 742$

Karlin A (1967): On the application of a "a plausible model" of allosteric proteins to the receptor for acetylcholine. J Theor Biol 16:306-320

Katz B, Thesleff S (1957): A study of the "desensitization" produced by acetylcholine at the motor end-plate. J Physiol 138:63-80

Keenan RM, Jenkins AJ, Cone EJ, Henningfield JE (1995): Smoked and i.v. nicotine, cocaine and heroin have similar abuse liability. Abstracts, Am Soc Addic Med 8th National Conference on Nicotine Dependence, Toronto, October 12-15

Kenakin TP (1993): Pharmacologic Analysis of Drug-Receptor Interaction, 2nd ed. New York, Raven Press

Knott VJ (1989): Brain event-related potentials (ERPs) in smoking performance research. In Ney T, Gale A (eds), Smoking and Human Behavior, chap. 5. New York, John Wiley and Sons, pp 93-114

Ksir C, Hakan R, Hall DP, Kellar KJ (1985): Exposure to nicotine enhances the behavioral stimulant effect of nicotine 
and increases binding of $\left[{ }^{3} \mathrm{H}\right]$ acetylcholine to nicotinic receptors. Neuropharmacology 24:527-531

Ksir C, Hakan RL, Kellar KJ (1987): Chronic nicotine and locomotor activity: Influences of exposure dose and test dose. Psychopharmacology 92:25-29

Kubo T, Fukuda K, Mikami A, Maeda A, Takahashi H, Mishina M, Haga T, Hata K, Ichiyama A, Kangawa K, Kojima M, Matsuo H, Hirose T, Numa S (1986): Cloning sequencing and expression of the complementary DNA encoding the muscarinic acetylcholine receptor. Nature 323:411-416

Lake JR, Upchurch TP, Shenoi M, Rajan N, Schweinle WE, Johnson SC, Malin DH (1997): Nicotine abstinence syndrome precipitated by the competitive nicotinic antagonist dihydro- $\beta$-erythroidine (DH $\beta E)$. Abst Soc Neurosci 23:257

Larson PS, Silvette H (1968): Tobacco Experimental and Clinical Studies: A Comprehensive Account of The World Literature, Suppl. 1. Baltimore, Williams and Wilkins

Larson PS, Silvette H (1971): Tobacco Experimental and Clinical Studies: A Comprehensive Account of the World Literature, Suppl 2. Baltimore, Williams and Wilkins

Larson PS, Haag HB, Silvette H (1961): Tobacco Experimental and Clinical Studies: A Comprehensive Account of the World Literature. Baltimore, Williams and Wilkins

Leischow SJ, Nilsson F, Franzon M, Hill A, Otte P, Merikle EP (1996): Efficacy of the nicotine inhaler as an adjunct to smoking cessation. Am J Health Behav 20:264-371

Lena C, Changeaux JP (1993): Allosteric modulations of the nicotinic acetylcholine receptor. Trends Neurosci 16: 181-186

Leutje CW, Patrick J (1991): Both alpha- and beta-subunits contribute to the agonist sensitivity of neuronal nicotinic acetylcholine receptors. J Neurosci 11:837-845

Li CQ, Longmire AW, Kramer ED, Wright C (1997): Doses of nicotine replacement therapy (NRT). Clin Pharmacol Ther 61:190

Lichtensteiger W, Hefti F, Felix D, Huwyler T, Melamed E, Schlumpf M (1982): Stimulation of nigrostriatal neurons by nicotine. Neuropharmacology 21:963-968

Lindstrom J, Schoepfer R, Conroy WG, Whiting P (1990): Structural and functional heterogeneity of nicotinic receptors. In Bock G, Marsh J, (eds), The Biology of Nicotine Dependence, Ciba Foundation Symposium 152. New York, John Wiley \& Sons, pp 23-52

London ED, Waller SB, Samsley JK (1985): Autoradiographic localization of $\left[{ }^{3} \mathrm{H}\right]$ nicotine binding sites in the rat brain. Neurosci Lett 53:179-184

Lucchesi BR, Schuster CR, Emley AB (1967): The role of nicotine as a determinant of cigarette smoking frequency in man with observations of certain cardiovascular effects associated with the tobacco alkaloid. Pharmacol Ther 8:789-796

McGehee DS, Heath MJS, Gelber S, Devay P, Role LW (1995): Nicotine enhancement of fast excitatory synaptic transmission in CNS by presynaptic receptors. Science 269:1692-1696

Marks MJ, Collins AC (1982): Characterization of nicotine binding in mouse brain and comparison with the binding of $\alpha$-bungarotoxin and quinuclidinyl benzilate. Mol Pharmacol 22:554-564
Marks MJ, Romm E, Gaffney DK, Collins AC (1986): Nicotine-induced tolerance and receptor changes in four mouse strains. J Pharmacol Exp Ther 237:809-819

Martin BR, Aceto MD (1981): Nicotine binding sites and their localization in the central nervous system. Neurosci Behav Rev 5:473-478

Mereu G, Yoon KWP, Boi V, Gessa GL, Naes L, Westfall TC (1987): Preferential stimulation of ventral tegmental area dopaminergic neurons by nicotine. Eur J Pharmacol 141:395-399

Mesulam MM (1994): Structure and function of cholinergic pathways in the cerebral cortex, limbic system, basal ganglia, and thalamus of the human brain. In Bloom FE, Kupker DJ (eds), Psychopharmacology: The Fourth Generation of Progress, chap. 12. New York, Raven Press, pp 135-146

Molander L, Lunell E, Andersson SB, Kuylenstierna F (1996): Dose related and absolute bioavailability of nicotine from a nicotine vapor inhaler. Clin Pharmacol Ther 59:394-400

Morrison CF (1967): Effects of nicotine on operant behavior of rats. Int J Neuropharmacol 6:229-240

Morrison CJ, Stephenson JA (1972): The occurrence of tolerance to a central depressant action of nicotine. Br J Pharmacol 46:151-156

Ney T, Gale A (eds) (1989): Smoking and Human Behavior. New York, John Wiley \& Sons, pp 1-383

Nisell M, Nomikos GG, Svensson TH (1994): Systemic nicotine-induced dopamine release in the rat nucleus accumbens is regulated by nicotinic receptors in the ventral tegmental area. Synapse 16:36-44

Nisell M, Nomikos GG, Svensson TH (1995): Nicotine dependence, midbrain dopamine systems and psychiatric disorders. Pharmacol Toxicol 76:157-162

Nisell M, Nomikos GG, Hertel P, Panagis G, Svensson TH (1996): Condition-independent sensitization of locomotor stimulation and mesocortical dopamine release following chronic nicotine treatment in the rat. Synapse 22:369-381

Nisell M, Marcus M, Nomikos GG, Svensson TH (1997): Differential effects of acute and chronic nicotine on dopamine output in the core and shell of the rat nucleus accumbens. J Neural Transm 104:1-10

Norman TR, Chamberlain KG, French MA, Burrows GD (1982): Platelet monoamine oxidase activity and cigarette smoking. J Affective Disorder 4:73-77

Norman TR, Chamberlain KG, French MA (1987): Platelet monoamine oxidase: Low activity in cigarette smokers. Psychiatry Res 20:199-205

Numa S, Noda M, Takahashi H, Tanabe T, Toyosoto M, Furatani Y, Kikyotani S (1983): Molecular structure of the acetylcholine receptor. Cold Spring Harbor Symp Quant Biol 48:57-69

Oreland L, Fowler CJ, Schalling D (1981): Low platelet monoamine oxidase activity in cigarette smokers. Life Sci 29:2511-2518

Pankow JF, Mader BT, Isabelle LM, Luo W, Pavlich A, Liang C (1997): Conversion of nicotine in tobacco smoke to its volatile and available free-base form through the action of gaseous ammonia. Environ Sci Technol 31:2428-2433

Paton WDM (1961): A theory of drug action based upon the 
rate of drug-receptor combination. Proc R Soc Lond (Biol) 154:21-69

Pomerleau CS (1997): Co-factors for smoking and evolutionary psychobiology. Addiction 92:397-408

Popot JL, Sugiyama H, Changeaux JP (1976): Studies on the electrogenic action of acetylcholine with Torpedo Marmorate electric organ II. The permeability response of the receptor-rich membrane fragments to cholinergic agonists in vitro. J Mol Biol 106:469-483

Porchet HC, Benowitz NL, Sheiner LB, Copeland JR (1987): Apparent tolerance to the acute effect of nicotine results in part from distribution kinetics. J Clin Invest 80:14661471

Porchet HC, Benowitz NL, Xheiner LB (1988): Pharmacodynamic model of tolerance: Application to nicotine. J Pharmacol Exp Ther 244:231-236

Pratt WB, Taylor P (eds) (1990): Principles of Drug Action. The Basis of Pharmacology, 3rd ed. New York, Churchill Livingstone

Rand MJ, Thurau K (1988): The Pharmacology of Nicotine. Washington, DC, ICSU Press by IRL Press, pp 1-418

Reiner PB, Fibiger HC (1994): Functional heterogeneity of central cholinergic systems. In Bloom FE, Kupfer DJ (eds), Psychopharmacology: The Fourth Generation of Progress. New York, Raven Press, pp 147-153

Richelson E (1994): Cholinergic transduction. In Bloom FE, Kupfer DJ (eds), Psychopharmacology: The Fourth Generation of Progress, chap. 11. New York, Raven Press, pp 125-134

Romano C, Goldstein A (1980): Stereospecific nicotine receptors on rat brain membranes. Science 210:647-650

Rose JE, Levin ED (1991): Inter-relationships between conditioned and primary reinforcement in the maintenance of cigarette smoking. Br J Addict 86:605-609

Rosecrans JA (1971): Effects of nicotine on behavioral arousal and brain 5-hydroxytryptamine function in female rats selected for differences in activity. Eur J Pharmacol 14:29-37

Rosecrans JA (1995): The psychopharmacological basis of nicotine's differential effects on behavior: Individual subject variability in the rat. Behav Genet 25:187-196

Rosecrans JA, Stimler CA, Hendry JS, Meltzer LT (1989): Nicotine-induced tolerance and dependence in rat and mice: Studies involving schedule-controlled behavior. Prog Brain Res 79:239-248

Rosecrans JA, Karan LD, James JR (1995): Nicotine as a discriminative stimulus: Individual variability to acute tolerance and the role of receptor desensitization. In Clarke BPS, Quik M, Adlkofer F, Thurau K (eds), Effects of Nicotine on Biological Systems II. Basel, Birkhäuser Verlag, pp 219-224

Russell MAH, Stapleton JA, Feyerabend C (1995): Nicotine boost per cigarette as the controlling factor of intake regulation by smokers. In Clarke PBS, Quik M, Adlkofer F, Thurau K (eds), Effects of Nicotine on Biological Systems II. Berlin, Birkhäuser Verlag, pp 233-238

Sargent PB (1993): The diversity of neuronal nicotinic acetylcholine receptors. Annu Rev Neurosci 16:403-443

Schleifer LS, Eldefrawi ME (1974): Identification of the nicotinic and muscarinic acetylcholine receptors in subcellular fractions of mouse brain. Neuropharmacology 13:53-63.

Schmeltz I, Hoffmann D (1976): Chemical studies on tobacco smoke. In Wynder EL, Hoffmann D, Gori B (eds), Modifying The Risk for the Smoker, vol I, chap. 38, DHEW Publication No. 76-1221. Washington, DC, US Government Printing Office, pp 13-84

Schulz DW, Loring RH, Aizenman E, Zigmond RE (1991): Autoradiographic localization of putative nicotinic receptors in the brain using $\left[{ }^{125}\right]$ neuronal bungarotoxin. J Neurosci 11:287-297

Schwartz RD, Kellar KJ (1985): In vivo regulation of [3]acetylcholine recognition sites in brain by nicotinic cholinergic drugs. J Neurochem 45:427-433

Schwartz RD, McGee R, Kellar KJ (1982): Nicotinic cholinergic receptors labeled by $\left[{ }^{3} \mathrm{H}\right]$ acetylcholine in rat brain. Mol Pharmacol 22:56-62

Schwartz RD, Lehmann J, Keller KJ (1984): Presynaptic nicotinic cholinergic receptors labeled by $\left[{ }^{3} \mathrm{H}\right]$ acetylcholine on catecholamine and serotonin axons in brain. J Neurochem 42:1495-1498

Seguela P, Wadiche J, Dineley-Miller K, Dani JA, Patrick JW (1993): Molecular cloning, functional properties and distribution of rat brain $\alpha 7$ : A nicotinic cation channel highly permeable to calcium. J Neurosci 13:596-604

Sershen H, Reith MEA, Lajtha A, Gennaro J Jr (1981): Noncholinergic saturable binding of $( \pm)-\left[{ }^{3} \mathrm{H}\right]$ nicotine to mouse brain. J Receptor Res 2:1-15

Shoaib M, Schindler CW, Goldberg SR (1997): Nicotine selfadministration in rats: strain and nicotine pre-exposure effects on acquisition. Psychopharmacol 129:35-43

Sieghart W (1992): Ligand-gated $\mathrm{Cl}^{-}$ion channels modulated by multiple drug-binding sites. Trends Pharmacol 13:446-450

Silver AA, Sanberg PR (1993): Transdermal nicotine patch and potentiation of haloperidol in Tourette's syndrome. Lancet 342:182

Sloan JW, Martin WR, Todd GD (1983): Multiple nicotine binding sites in rat brain $\mathrm{P}_{2}$ fraction. Psychopharmacol Bull 19:402-408

Sloan JW, Todd GD, Martin WR (1984): Nature of nicotine binding to rat brain $\mathrm{P}_{2}$ fraction. Pharmacol Biochem Behav 20:899-909

Sloan JW, Martin WR, Hernandez J, Hook R (1985a): Binding characteristics of (-)- and (+)-nicotine to the rat brain $\mathrm{P}_{2}$ fraction. Pharmacol Biochem Behav 23:987-993

Sloan JW, Martin WR, Hook R, Bostwick M, Howell A, Smith WT (1985b): Stereospecificity of 2-methylpiperidine binding to a nicotinic up-regulatory site in the rat brain $\mathrm{P}_{2}$ preparation. Life Sci 37:1367-1372

Sloan JW, Martin WR, Hook R, Hernandez J (1985c): Structure-activity relationships of some pyridine, piperidine, and pyrrolidine analogues for enhancing and inhibiting the binding of $( \pm)-\left[{ }^{3} \mathrm{H}\right]$ nicotine to rat brain $\mathrm{P}_{2}$ preparation. J Med Schem 2228:1245-1251

Sloan JW, Martin WR, Smith WT (1987): Multiple nicotinic receptors: Nicotinic ligands with different specificities. In Martin WR, Van Loon GR, Iwamoto ET, Davis L (eds), Tobacco Smoking and Nicotine. New York, Plenum Press, pp 451-465 
Sloan JW, Martin WR, Bostwick M, Hood R, Wala E (1988): The comparative binding characteristics of nicotine ligands and their pharmacology. Pharmacol Biochem Behav 30:255-267

Smith CJ, Giacobini E (1992): Nicotine, Parkinson's and Alzheimer's disease. Rev Neurosci 3:25-42

Steinbach JH (1990): Mechanism of action of the nicotinic acetylcholine receptor. In Bock G, Marsh J (eds), The Biology of Nicotine Dependence, Ciba Foundation Symposium 152. New York, John Wiley \& Sons, pp 53-67

Stephenson RPA (1956): A modification of receptor theory. Br J Pharmacol 11:379-393

Stolerman IP (1989): Discriminative stimulus effects of nicotine in rats trained under different schedules of reinforcement. Psychopharmacology 97:131-138

Stolerman IP, Fink R, Jarvik ME (1973): Acute and chronic tolerance to nicotine measured by activity in rats. Psychopharmacology 30:329-342

Svensson TH, Grenhoff J, Enberg G (1990): Effects of nicotine on dynamic function of brain catecholaminergic neurons. In Bock G, Marsh J (eds), The Biology of Nicotine Dependence, Ciba Foundation Symposium 152. New York, John Wiley \& Sons, pp 169-185

Swanson LW, Simmons DM, Whiting PJ, Lindstrom J (1987): Immunohistochemical localization of neuronal nicotinic receptors in the rodent central nervous system. J Neurosci 7:3334-3342

Tarroni P, Rubboli F, Chini B (1992): Neuronal-type nicotinic receptors in human neuroblastoma and small-cell lung carcinoma cell lines. FEBS Lett 312:66-70

Tessari M, Valerio E, Chiamulera C, Beardsley PM (1995): Nicotine reinforcement in rats with histories of cocaine self-administration. Psychopharmacology 121:282-283

Thron GW (1973): On the analysis of pharmacological experiments in terms of an allosteric receptor model. Mol Pharmacol 9:1-9

US Surgeon General's Report (1988): The Health Consequences of Smoking: Nicotine Addiction. Washington, DC, US Department of Health and Human Services, pp 1-639

Vidal C (1994): Nicotinic potentiation of glutamatergic syn- apses in the prefrontal cortex: New insight into the analysis of the role of nicotinic receptors in cognitive function. Drug Dev Res 31:120-126

Villaneuva S, Arezo JR, James JR, Rosecrans JA (1992): A characterization of nicotine-induced tolerance: Evidence of pharmacological tolerance in the rat. Behav Pharmacol 3:255-260

Wada E, Wada K, Boulter J, Deneris E, Heineman S, Patrick J, Swanson LW (1989): Distribution of alpha 2, alpha 3, and alpha 4 , and beta 2 neuronal nicotinic receptor subunit mRNAs in the central nervous system: A hybridization histochemical study in the rat. J Comp Neurol 284:314-335

Waldo M, Carey G, Myles-Worsley M, Cawthra E, Adler LE, Nagamoto HT, Wender P, Byerley W, Plaetke R, Freedman R (1991): Codistribution of a sensory gating deficit and schizophrenia in multi-affected families. Psychiatry Res 39:257-268

Winchell CJ, Wright C, Burke L et al. (1997): Long-term abstinence in users of OTC nicotine replacement. Clin Pharmacol Ther 61:191

Wonnacott S (1990): The paradox of nicotinic acetylcholine receptor up-regulation by nicotine. Trends Pharmacol $11: 216-219$

Wonnacott S (1997): Presynaptic nicotinic ACh receptors. Trends Neurosci 20:92-98

Wonnacott S, Irons J, Rapier C, Thorne B, Lunt GG (1989): Presynaptic modulation of transmitter release by nicotinic receptors. In Nordberg A, Fuxe $\mathrm{H}$, Holmstedt B, Sundwall A (eds), Progress in Brain Research. Amsterdam, Elsevier, pp 157-163

Yoshida K, Imura H (1979): Nicotinic cholinergic receptors in brain synaptosomes. Brain Res 172:453-459

Yu PH, Boulton AA (1987): Irreversible inhibition of monoamine oxidase by some components of cigarette smoke. Life Sci 41:675-682

Zhang M, Wang YT, Vyas DM, Neuman RS, Bieger D (1993): Nicotinic cholinoceptor-mediated excitatory postsynaptic potentials in rat nucleus ambiguus. Exp Brain Res 96:83-88 